\title{
Student Entrepreneurship Education Effort Through Kopsis (Student Cooperative) in Bandung
}

\author{
Neti Budiwati, Yana Rohmana \\ Program Studi Pendidikan Ekonomi \\ Universitas Pendidikan Indonesia \\ Bandung, Indonesia \\ netibudiwati@upi.edu
}

\begin{abstract}
This study was conducted to analyze factors related to internal and external development model of entrepreneurship education students through cooperative school (Kopsis) through SWOT analysis method. This research is a descriptive study subjects of the study are the administrators and coaches Kopsis in SMA / SMK in Bandung. The purpose of this research was to obtain a general overview of the condition of the student cooperative, which can be used development of education model of the student cooperative. Collecting data with survey / observation, interviews, and documentation. The results of research related to entrepreneurship education efforts through Kopsis in Bandung to the conclusion that: (i) entrepreneurship education for high school / vocational school is very important, and the process of its development can be done in stages; (ii) Among the most effective means in the process of entrepreneurship education in schools is to empower students Cooperative institutions Students (Kopsis), therefore Kopsis school management must be properly managed; and (iii) are at least four important concepts to consider in the promotion and development of entrepreneurship students at school Ten indicators of the strength and ten indicators of the opportunities that exist to help administrators and coaches Kopsis to be implemented for the development and success of cooperatives. The elements of existing weaknesses that gets serious attention both by the board and adviser Kopsis as well as by the members, and can anticipate the threats that exist in order to live and grow and be able to realize the expected success.
\end{abstract}

Keywords - education, entrepreneurship, students, students cooperative

\section{INTRODUCTION}

One key advancement of the Indonesian economy is through cooperatives. Therefore, the cooperative must be turned from an early age through education. We know that the facts on the ground prove cooperatives and small and mediumsized enterprises able to survive the current economic crisis hit Indonesia. In addition there are many issues of economic sovereignty controlled by foreigners. One of them is the capitalist market forces increasingly dominate all Indonesian economy. The traditional market is gradually shifted in the role of balancing the economic condition in Indonesia. Therefore, there needs to be an institution that is able to improve the economic structure and Pancasila democracy i.e. the cooperative.
Provisions on the economy has been provided in article 33, paragraph 1 of the 1945 Constitution reads, "The economy is structured as a joint effort based on the principle of kinship." Indonesia already has institutions that stand by the principle of kinship that is cooperative. One way that can be developed is cooperat education ive with the term Kopsis (Cooperative school) and Kopma (Student Cooperative) in education. But, both of them have not run optimally as other general cooperatives.(1)

Some student cooperative in Bandung and generally also in Indonesia has experienced a near-death and switching functions. Kopsis should be a field for students to learn management and organization. However, some schools simply be Kopsis as a tool for business. The role of the students only provide primary deposits and deposit required, while running the cooperative teachers and school employees. It is very unfortunate if it is not turned on and maximized. Kopsis is a miniature cooperatives in Indonesia. Based on family principles, Kopsis expected to help students discover the identity of a community-based economy of Indonesia, Pancasila and give priority to the interests together.

We know that it is a form of regeneration Kopsis Indonesia's economic future. Through cooperative education from an early age, children are expected soul kinship can be formed. Kids can progress through the cooperative. Not only in terms of materials, can children also learn to manage emotions when faced with the problems. As the field of cooperative education, Kopsis has a big role. Therefore, the establishment of Kopsis in each school is expected. Kopsis established shape can be either cooperative consumption or services. Kopsis can sell the equipment of the school and the students' work. The existence Kopsis can motivate students to be creative according to their individual potential. Indirectly this may stimulate the entrepreneurial spirit of students from an early age.(2)

Entrepreneurial spirit from an early age is very necessary. Today, the strong are daring to compete in the marketplace. By learning from an early age, children will learn more about the economy and independence. Children will be more critical when faced with competitiveness and quality improvement. Cooperative is not everything, but the brightness of the Indonesian economy could come from there. Time to take on the role of schools and reviving the Indonesian cooperatives to better students in the era globalization today. 
Realizing such conditions, it is necessary to research which has the objective to produce a education model as to what to do to be able to act according to expectations Kopsis and able to attract students into entrepreneurship in the future. In the first phase the focus of this study is to analyze what are the internal factors such as the strength (Strengths) and weaknesses (weaknesses), as well as external factors such as opportunities (Opportunities) and threats (Threats) of the development model of entrepreneurship education students through cooperative students ( Kopsis) in the city of Bandung.

\section{LITERATURE REVIEW}

\section{A. Basic Concepts of Student Cooperative}

Cooperative students often called Kopsis is a cooperative that is in the school environment and managers are members of the school students themselves. The presence Kopsis rated as one form of extracurricular activities both in the school environment. In the three ministerial decree No. SKB-125 / M / SBC / X / 1984; No. 0447a / U / 1984 and No. 71 of 1984, said that the purpose of Cooperative Educational or Kopsis is to further improve the capability and well-being of the students in the effort to accelerate the process of education and efforts to promote cooperatives.

It is known that the purpose of the student cooperative more operational are:

- As a practical and cooperative education and entrepreneurship for students.

- To meet the needs of students for example, school equipment, school books and other services.

- To educate, instill and maintain an awareness of life and work together and the sense of solidarity among students.

- To foster a sense of love for the school.

- To maintain and develop the best businesses enhance the quality of knowledge and skills.

\section{B. Organization and Management Cooperative}

Generally, the cooperative are economic organization is managed its members on the basis of one man one vote. (3) Cooperatives can be defined, as stated in the Cooperative Law No. 25/1992: Is a business entity consisting of a person or legal entity with the bases cooperative activities based on the principle of cooperation as well as people's economic movement based on principles of kinship.

The cooperative has two principal functions, including:

- The function of education, in this case serves as a cooperative organization that can provide value-added quality scientific cadre maturation. In this case, especially concerning aspects of entrepreneurship and cooperatives.

- Business function, this function is a distinct advantage for the cooperative because the only cooperative that has this function. With this function, the cooperative could establish and develop business units and can serve as laboratory business for its members.(4)

Of the main functions of the cooperative is the function of the existence of cooperative education students (Kopsis) is a form of achieving cooperative functions.

Student cooperative is a cooperative whose members consist of students of the school in question, such as elementary school students, junior high school students, High School, Vocational High Schools, Boarding Schools and other educational institutions are similar. Namely the existence of cooperative schools to meet student needs. In addition, as a learning tool for the students themselves. Cooperative students, including one form of special cooperative cooperative intention is not a legal entity but may engage in economic activities. And although not a legal entity, but Kopsis still recognized by the Government as an association. Recognition of this government is the license to run the activities of the cooperative.

The characteristics of student cooperation is:

- Cooperation established within the framework of students learning activities the students in the school

- The members are among students at your school

- Since the establishment of cooperatives is related to learning, it is not required to be incorporated.

- Serves as cooperative teaching laboratories in schools

Students Cooperative Principles is based on the Cooperative Act 25 of 1992 Chapter II Article 2 states that the principle of Cooperative Indonesia is familial. Mandates the principle of family kinship spirit.

Cooperative students did not receive recognition as a legal entity cooperative, but as an economic institution with character social, cooperative school has foundation, principles, and joints of the same basis as of cooperatives in general. The difference cooperative student with cooperatives in general, lies in the purpose, function and role.

\section{Students Entrepreneurship Education Through Student Cooperative in the School}

Based on the Ministry of Education and Culture No. 0461 / U / 1984, Pattern of Student Promotion and Development explained that, two of the eight student coaching materials are:

- Development of personality and noble character; and

- Coaching skills and entrepreneurial students.

One way in fostering students' skills and entrepreneurial aspect is any educational institution should exist Student Cooperative (Kopsis), in the form of cooperative education. Cooperative education is: "... an academic program integrating classroom learning and productive work experiences in a field related to a student's academic and career goals. Co-op provides students with progressive learning experiences integrating theory and practice. As an academic program, coop serves as a partnership among students, educational institutions, and employers. (World Association for Cooperative Education, 2014-2015) (5) 


\section{METHODOLOGY}

This research was conducted by the method of SWOT analysis. This analysis was conducted to identify factors that influence entrepreneurship education students through Kopsis in order to obtain a formulation model of development and the fight routine and organized so that the role and function of the corresponding identity Kopsis can develop well. From the SWOT analysis will be known to internal factors such as the strength (Strengths) and weaknesses (Weaknesses), as well as external factors such as opportunities (Opportunities) and threats (Threats) of the development model of entrepreneurship education students through student cooperative (Kopsis). This research is a descriptive study subjects of the study are the administrators and coaches Kopsis in SMA / SMK in Bandung. Collecting data with survey / observation, interviews, and documentation.

\section{RESULTS AND DISCUSSION}

Based on survey results, interviews, and documentation obtained information that in the city of Bandung has a lot of good high school or vocational school students who already have a cooperative, although that already have also not run according to the rules and expectations. In the future there must be improvement of the administrators and supervisors Kopsis and related parties (stakeholders) such as the Department of Education, Department of Cooperatives, and others to continue to promote and develop Kopsis as a learning tool in the formation of student interest and entrepreneurial spirit. The principal goal of any educational program is to facilitate student learning. In educational programs, assessment is intrinsically linked to student learning and performance. In cooperative education, this learning largely occurs in two milieu: the educational institution and the workplace. (6)

Here are the results of a SWOT analysis related Student Cooperatives conditions existing in Vocational School (SMK) Bandung.

\section{A. Strength, include :}

- Membership is open and voluntary, and many made the clear market

- There has been some student cooperative (Kopsis) SMA / SMK which has legal entity, although it is not an obligation.

- Management of a democratic and open Structure organizations that are in accordance with the provisions of the cooperative school.

- The availability of support facilities Kopsis already good at some schools

- Risk of shortage of customers is quite small.

- Low cost.

- The establishment of several schools in the complex / the same place makes a big potential market share

- School location close to business centers, offices, and other strategic places
- The number of business units that have been wellmanaged and profitable

- Guidance Kopsis supportive and many parties

B. Weakness, include

- The low structure cooperative capital for business development Kopsis

- Weakness in the management / business management Kopsis.

- Room for Kopsis of the school is still limited / small

- Lack of awareness of members of their rights and obligations (low member participation).

- Have difficulty determining the core business

- The timing of this activity is still relatively less Kopsis

- Lack of knowledge of business managers of cooperatives.

- Do not have the strength of cooperatives, both institutionally and administrative.

- Less in control technology.

- Lack of business experience.

- Managers are less innovative.

C. Oportunities, include :

- Schools are already there that has good Internet network for communications and marketing programs including product Kopsis.

- Support policies of schools, government and related parties will progress Kopsis

- Many programs correspond to school cooperative programs, particularly in government agencies and private companies

- Strong political will from the government and growing demands of society to further establish cooperative.

- Economic conditions sufficient for the existence of the cooperative.

- The world economy is increasingly open resulting in further opening up international markets for the results of Indonesian cooperatives.

- The existence of a market opportunity for the commodities produced by the cooperative.

- An investor who wants to cooperate with the cooperative.

- Purchasing power is high.

- Transaction sharia on economic institutions have already begun 
D. Threats, include:

- The low level of awareness, ability and quality builder in Kopsis

- Lack of participation in the activities of members of the cooperative efforts Kopsis

- The presumption that people are still negative or indifferent to the cooperative.

- Different perceptions of apparatus builder cooperative.

- Competition with other agencies increasingly stringent.

- There is still a lack of confidence to work together with other economic actors and among cooperatives.

- Limited deployment and provision of national technology for the cooperative.

- Lack of awareness and understanding of cooperatives as well as the lack of awareness and public confidence in the cooperative.

- Free market.

- Lack of effective coordination and synchronization in the implementation of development programs Kopsis.

- The business environment is not conducive

It must be realized that the SWOT analysis above is the result of the analysis of the majority of high school / vocational school in Bandung, so the schools need to be wise in negotiating that conditions. There are some Kopsis that has both management and identity but not least also Kopsis are still not according to the rules and expectations. But, hopefully the future all parties can act in accordance with their share so that Kopsis as incubators formation of interest and entrepreneurial spirit early can be a great hope for the progress of this nation in the future.

Ten indicators of the strength and ten indicators of the opportunities outlined above can help administrators and coaches Kopsis to be implemented for the development and success of cooperatives. The elements of existing weaknesses that gets serious attention both by the board and adviser Kopsis as well as by the members, so that the risks arising from these weaknesses can be minimized so that the successful and cooperative development can be achieved. Necessary for the management and coaches Kopsis to be able to anticipate the threat in order to live and grow and be able to realize the expected success.

The existence of Student cooperative (Kopsis) in any educational institution has an important role in the process of entrepreneurship education students, then the control or management Kopsis in the schools should be done with the best, and actually serve as a practice and training for students in building and developing the mental attitude entrepreneurship. So the parties the above should continue to pay attention to how the process of guiding or train students to develop entrepreneurial potential and founding in the school environment, among others through some of the program (7) :
1) In order to raise and cultivate students' interest towards entrepreneurial activities among others:

- Writing stories about successful entrepreneurs figure;

- Competition read and write poetry about the entrepreneurial spirit;

- Visits to places of business or industry; and

- Lectures and discussions entrepreneurial leaders who succeed in school.

2) In order to enhance their entrepreneurial skills among others:

- Practice the art of selling skills, gardening, livestock, sewing, cooking, decorating, planting, services etc.;

- Implement student paper competition.

3) In order to enhance their mental attitude to entrepreneurship, among others:

- The use of learning tools such as books, audio-visual, computer, internet and other means of skill;

- The practice of real work;

- Savings entrepreneurship students to meet learning needs;

- Through student media (news students) communicated fond of entrepreneurship;

- Camping and social services

4) In order to develop thinking and acting creatively and productively, among others:

- Competition papers students about entrepreneurship;

- Competition copyrighted means of production;

- Writing reference books on entrepreneurship;

- Upgrading instructors entrepreneurship;

- Into entrepreneurial forum of students and for students;

- Develop a planning through the creation of project proposals student activities; and

- Carry out feasibility studies, surveys and research on entrepreneurship.

\section{CONCLUSION}

The results of research related to entrepreneurship education efforts through Kopsis in the school in Bandung provide the following conclusions: (a) entrepreneurship education for high school / vocational school is very important, and the process of its development can be done in stages; (B) Among the most effective means in the process of entrepreneurship education in schools is to empower students Cooperative institutions Students (Kopsis), therefore Kopsis school management must be properly managed; and (c) are at least four important concepts to consider in the promotion and 
development of entrepreneurship students in schools (as described above).

\section{1) Suggestion}

- Cooperative activities students should continue to be developed and integrated with the business center thereby building positive character values on students

- Attention and material and non-material support for the government against Kopsis necessary to instill or preserve the cooperative to the younger generation.

- Keep the guide books Kopsis development of a structured and planned.

\section{REFERENCES:}

(1) Abrahamsen, Martin A, Co-operative Business Enterprise, Mc.Grow Hill Book Company USA, 1976, p 4

(2) Sari, Dea Prilia, Efektivitas Peran Koperasi Sekolah sebagai Unit Pembelajaran Kewirausahaan di SMP Negeri 1 Karanganyar Kabupaten Pekalongan, Economic Eduacation Analisys Journal, EEAJ 2 (1), 2013, p15

(3) Lilis Lindawati, M, Suyanto, Peran Koperasi Sekolah dalam Meningkatkan Sikap Kewirausahaan Siswa SMK Negeri I Wonogiri, Jurnal Pendidikan IPS, Vo. 1 No. 2, 2015, P170180

(4) Ropke, J, Djatnika, S, Ekonomi Koperasi, Salmba Empat Jakarta, 2003, p21-27

(5) Linn, Patricia, A lifespan perspective on cooperative education learning: A grounded theory, Asia-Pacific Journal of Cooperative Education, Vol 16 Issue 4, 2015, p1

(6) Hodges, D, Eames, C, Coll, R K, Theoretical perspectives on assessment in cooperative education placements, Asia-Pacific Journal of Cooperative Education, Vol 15 Issue 3, 2014, p1

(7) Arifin, Pendidikan Kewirausahaan Siswa Melalui Kopsis Sekolah, Tersedia di https://drarifin.wordpress.com, 25-6-2014 